\title{
Ett jubileum: Det tionde numret av NorDiNa
}

Välkommen till volym 5 av NorDiNa år 2009. Det är ju en form av jubileum när vi nu ger ut det tionde numret av vår tidskrift. Vi tar därför tillfället i akt att reflektera runt processen att upprätthålla en hög kvalitet på innehållet i varje nummer av NorDiNa. Förra året var specialutgåvornas år och i första numret presenterades artiklar från doktorander i Finland och Sverige. Andra numret var delvis ett vanligt nummer med två forskningsartiklar och en presentation av ett utvecklingsarbete och delvis ett specialnummer med utvalda artiklar från konferensen "The 9th Nordic Research Symposium on Science Education" i Reykjavik i juni 2008. Urvalet av konferensartiklar gjordes av den lokala kommittén för konferensen. Vid bägge tillfällen har våra gästredaktörer gjort ett omfattande och viktigt arbete med att både välja ut och kvalitetssäkra artiklarna.

Detta första nummer år 2009 är ett alldeles "vanligt" NorDiNa-nummer. Men varje nummer har ju sin speciella sammansättning av alldeles unika artiklar producerade i anletes svett av våra kära författare och som sedan blivit kvalitetsgranskade av två oberoende referees. Efter detta arbete skriver vi i redaktionen en sammanfattning av de båda refereepersonernas kommentarer och inte sällan lägger vi till en del kommentarer för egen del då vi läser och sammanfattar. Allt i en strävan att ge er författare en så god förutsättning som möjligt att revidera ert manuskript. Vi begär också en revisionsrapport så vi kan följa hur ni förhålligt er till de kommentarer ni fått från både referees och redaktion. Det är ju fullt möjligt att ni avvisar en del kommentarer och att detta dessutom sker på vetenskapligt acceptabla grunder. Ibland tvingas vi avvisa ett manuskript vilket alltid är en smärtsam process, främst för författare förståss, men också för oss i redaktionen. Vi vet dessutom att det för många referees är tungt att avvisa ett manuskript, men samtidigt är det viktigt för alla parter att vi håller kvaliteten hög i vår tidskrift. Även avvisade manuskript får en refereesammanfattning med kommentarer från både referees och redaktion och vår förhoppning är att dessa kommentarer är en hjälp för författaren att gå vidare med sitt skrivande av nya manuskript eller en mer omfattande revision av befintligt manuskript.

I detta nummer finns sju artiklar publicerade. Flera artiklar handlar om synen på, intresset av, uppfattningen om och användningen av naturvetenskap. En artikel handlar om ämnesintegrering, i en annan undersöker författarna implementering av ett undervisningsmaterial samt två artiklar som handlar om läsning av naturvetenskapliga texter.

Mats Lundström och Anders Jakobsson undersöker i sin artikel hur 300 elever i en enkät förhåller sig till science and pseudo-science. Deras resultat tyder på att eleverna behöver diskutera och kritiskt granska relationen mellan science och pseudosciense för att utveckla en förståelse av naturvetenskapens karaktär. Magnus Oscarsson, Anders Jidesjö, Karl-Göran Karlsson och Helge Strömdahl undersöker science in society or science in school. De studerar elever och lärares uppfattning om naturvetenskap och teknik. De fann en skillnad mellan vad lärare undervisade om och vad elever ville lära sig. I artikeln av Margareta Ekborg, Malin Ideland och Claes Malmberg under rubriken science for life önskar författarna beskriva a conceptual framework som kan användas 
för att analysera elevers arbete med socio-scientific issues (SSI). Helena Persson, Margareta Ekborg och Anders Garpelin undersöker i sin artikel ämnesintegrerad undervisning och hur lärare definierar och iscensätter detta. De fann två olika sätt, dels genom en integrering mellan de naturvetenskapliga skolämnena och dels en integrering med andra skolämnen. Fredrik Alm och Joakim Samuelsson studerar i sin artikel villkor för implementering av NTA (Naturvetenskap och Teknik för Alla) och fann att om NTA överensstämmer med lärarnas intensioner i undervisningen och synen på det innehåll som ska undervisas är avgörande om lärarna fortsätter men NTA-materielet. I två artiklar redovisar Stein Dankert Kolstø vektlegging av lesing $i$ naturfaget i första artikeln presenteras en review som visar att elever finner uppgiften att läsa naturvetenskapliga texter svår. I artikel två erbjuds läsaren ett "tool-kit" för läraren i naturvetenskap som kan användas för att ge eleverna instruktioner i att läsa naturvetenskapliga texter. I detta nummer finns dessutom hela nio avhandlingspresentationer, en från vardera Danmark, Finland och Norge samt sex från Sverige. Detta lovar gott för framtiden i vårt forskningsfält!

Utan referees kan vi inte producera några nya nummer av NorDiNa och vi vill passa på att tacka er för ert ovärderliga arbete för vår tidskrift. Det finns nu 97 olika personer som varit referees $\mathrm{i}$ NorDiNa vid en eller flera olika tillfällen. Vi riktar ett stort tack till alla referees som så välvilligt ställt upp för NorDiNa och därmed möjliggör att vi kan fortsätta ge ut NorDiNa med två nummer per år. Sedan sist har följande personer bidragit som referees:

Allyson MacDonald

Andreas Redfors

Andreas Quale

Ann Zetterqvist

Anna Vikström

Annette Lykknes

Astrid Tonette Sinnes

Björn Andersson

Bjørn Håland

Britt Lindahl

Christina Kärrqvist

Doris Jorde

Ellen Karoline Henriksen
Erik Knain

Frank Bach

Jari Lavonen

Jim Ryder

Jim Donnelly

Jonas Ivarsson

Kerst Boersma

Marcus Hammann

Margareta Ekborg

Marianne Ødegaard

Marianne Foss Mortensen

Michael Reiss

Miia Rannikmäe
Minkee Kim

Monica Rosén

Per Morten Kind

Per-Odd Eggen

Rie Popp Troelsen

Sibel Enduran

Silje Noack Fekjær

Stein Dankert Kolstø

Sverre Pettersen

Vivi Ringnes

Åke Ingerman

Åsa af Geijerstam

Med hopp om en skön vår med både skrivning för och läsning av NorDiNa!

Redaktörerna,

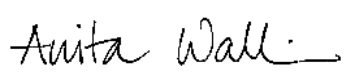

Anita Wallin

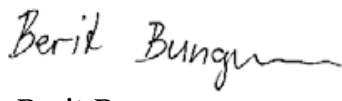

Berit Bungum

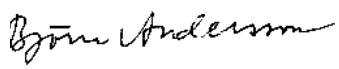

Björn Andersson 